\title{
An Analysis of Millennial Farmers' Communication Networks on Hydroponic Vegetable Marketing Topics Via Whatsapp Application (Hydroponic Farmers in Situbondo)
}

\author{
Sandis Wahyu Prasetiyo ${ }^{1 *}$, Edi Dwi Cahyono ${ }^{2}$, Reza Safitri ${ }^{2}$ \\ ${ }^{1}$ Balai Pengkajian Teknologi Pertanian Balitbangtan, Central Kalimantan Province, Jl. G. Obos Km 5 \\ Palangka Raya 73111, Indonesia \\ ${ }^{2}$ Sociology Study Program, Postgraduate Degree, Faculty of Agriculture, Universitas Brawijaya, Jl. \\ Veteran Malang 65145, Indonesia
}

Received: 27 June 2021; Revised: 23 July 2021; Accepted: 28 July 2021

\begin{abstract}
The large-scale social restrictions during the COVID-19 pandemic have hampered the communication process for millennial hydroponic farmers in Situbondo. The farmers could not have their regular offline meetings. As such, they started to switch to the Whatsapp messaging application to communicate. However, the switch was done without prior need analysis, so there was no guarantee of whether the application could meet their need to communicate. This study aimed to analyze the interpersonal communication network, WA media gratification, and the relationship between the two. The communication network method was used in this study by interviewing 108 respondents through a nominalist approach and positional strategy, small group sampling followed by intact sampling. Data were analyzed using the Communication Network Analysis program UCINET Version 6.0, descriptive analysis, and analysis of variable relationships using the SPSS Version 21. The results showed that the whole network consisted of actors from various professions and backgrounds from Situbondo and outside Situbondo. The communication network structure formed a wheel with the dominance centrality degree, closeness, betweenness, and eigenvector actors by three hydroponic farmers with codes 41, 47, and 105. The level of WA media gratification, included the use and satisfaction obtained by hydroponic farmers, was very high on information, socialization, and social support. The relationship between interpersonal communication networks and WA media gratification showed a significant and very significant relationship for socialization and social support.
\end{abstract}

Keywords: centrality; communication; hydroponic; gratification; WhatsApp

How to cite:

Prasetiyo, S. W., Cahyono, E. D., \& Safitri, R. (2021). An Analysis of Millennial Farmer s , Communication Networks on Hydroponic Vegetable Marketing Topics Via Whatsapp Application ( Hydroponic Farmers in Situbondo ). Habitat, 32(2), 101-112. https://doi.org/10.21776/ub.habitat.2021.032.2.12

\section{Introduction}

Information and Technology (IT) has been increasing rapidly, that it now can be used to share information globally, including in the agricultural sector (Daum, 2018).

During the Covid-19 pandemic, IT plays an even more significant role in keeping people connected from their homes (Király et al., 2020). In addition to being used by many sectors

*Correspondence Author.

E-mail: sandiswp@yahoo.com

Phone : 0813-3441-9996
(Trujillo Loli et al., 2021), during the Covid-19 pandemic, Whatsapp (WA) installed on smartphones has also played a major role in connecting farmers and people in the agricultural sector; WA has been considered effective for information sharing. Certain sectors have used smartphones for transforming the rural economy in developing countries, one of which is in specializing plants (Min et al., 2020). Hydroponic is one of the plant-specializing efforts focusing on planting methods. Hydroponic is increasingly popular as a new technology in producing vegetables using a water base. It produces higher quality crops with higher economic feasibility 
than land-based planting methods when land resources for agriculture are getting narrower (Majid et al., 2021).

The study was conducted after young farmers started to share information on marketing hydroponic lettuce in Situbondo Regency, East Java, Indonesia. WA as an internet-based IT medium is believed to be useful for marketing and positively increase farmer income (White et al., 2014; Profit et al., 2021). As such, farmers choose to use WA to accommodate their needs related to Gratification Sought (GS) and Gratification Obtained (GO) (Palmgreen et al., 1980). Information as one of the farmer's needs may come from senior and experienced farmers that can help to spread the information within a communication network (Freeman, 2016). Then, the information is exchanged within the marketing communication network to gain deals among individuals (Gallo, 2020). Within this context, WA unites farming communities in agricultural information systems according to their functional effectiveness in supporting the development (Naruka et al., 2017).

The network form also describes agricultural extension through ICT as a medium to increase the flow of information between individuals (Thakur et al., 2017; Dlamini \& Worth, 2019). Communication networks are formed by the interactions pattern representing the flow of messages between communicators, such as individuals, objects, and events over time (Rogers \& Kincaid, 1981). Network analysis functions to identify communication structures within the subsystems that affect behavior within such systems. The measure of network analysis at the individual level (actor) is called centrality. At this level, the actor has a prominent position or power in the network (Bonacich_1987.Pdf, n.d.). Knowing the individuals acting as the central actors in the hydroponic vegetable marketing network and the extent to which WA media gratification can meet the needs of hydroponic farmers are important for further studies.

The present study described an object or observed social phenomenon and a correlation showing the relationship of the hydroponic farmer's interpersonal network (Rogers dan Kincaid, 1981) on WA media gratification related to use and satisfaction on the use (Palmgreen et al., 1980). The communication network uses four indicators of centrality: degree, closeness, betweenness, and eigenvectors (Eriyanto, 2014). Gratification was measured using three indicators as the driving factor for individuals to use social media: information, socialization, and social support. The indicators were adopted from Bae (2018), stating that individuals formed social networks for information (Bondad-Brown et al., 2012), socialization (Han et al., 2015), and social support.

Within the communication network formed by the hydroponic farmers, degree centrality indicates the popularity of certain actors in the network characterized by the highest total number of relationship lines they form (Zhang \& Luo, 2017; Beaman \& Dillon, 2018). Closeness centrality shows how close a certain actor is to other actors. It means if these actors need to communicate with others, they do not have to go through many intermediaries, or they have the shortest number of node distances (steps) to other actors (Wehmuth \& Ziviani, 2013; Zhang \& Luo, 2017). Betweenness centrality indicates the position of a particular actor as a liaison for other actors in the network (Zhang \& Luo, 2017; Beaman \& Dillon, 2018). Eigenvector centrality shows the influence or importance of a person or party on a network (Ruhnau, 2000; Real et al., 2019).

Information, socialization, and social support sequentially explain Gratification Sought (GS) and Obtained (GO) by millennial hydroponic farmers through the use of WA in their communication networks. The internet as a modern medium of communication has a real impact on farmers related to access to market information and communication (socialization) with consumers (White et al., 2014). Socialization represents a manifestation of actual behavioral involvement in building social relationships in the network. Internet-based media can form social networks and influence the socialization of individuals on certain activities (Kizgin et al., 2019), including the agricultural sector. Internet-based media can also provide social support from individuals to others (Shensa et al., 2016; Shensa et al., 2020).

\section{Research Method}

\subsection{Method and Design}

The communication network methodology provides a very relevant approach and analysis regarding the relationship and position of individuals as actors in the network structure to see the relationship between actors (Eriyanto, 2014). The network methodology also provides attributive data of attitudes (opinions) towards 
media gratification. The communication network research design was used in the research framework to generate data. This study reported an analysis addressing three objectives: (1) identifying actors and analyzing marketing topics within a communication network at the individual level based on their centrality in the network; (2) analyzing WA media gratification used by hydroponic farmers; and (3) analyzing the relationship of the interpersonal communication network to WA media gratification. The selection of research locations purposively focused on the communication network formed by millennial hydroponic farmers cultivating lettuce in Situbondo Regency. The study was conducted for two months, from March to April 2021.

\subsection{Sample}

The population is determined based on the specific limitations of the nominalist approach and positional strategy (Eriyanto, 2014). It means that the definition of the communication network and member boundaries were based on a person's position within certain limits according to the conceptual framework proposed by the researchers. The population was ten known WA groups of hydroponic farmers in Situbondo. The total population was 171 people consisting of individuals as hydroponic farmers and nonhydroponic farmers (other professions).

Samples were chosen by employing the network method, namely the small group technique (Scott, 2000), taking only certain groups. Within this specific study, samples were hydroponic farmers in the ten WA groups. The total samples were 127 farmers. Respondents were chosen using intact sampling. We invited or met the farmers and asked them to fill in questionnaires offline to collect quality data (health protocol was strictly followed during offline data collection) or online by sending them questionnaires using a Google Form. Intact sampling was done because we understood that during the Covid-19 pandemic, some farmers would be reluctant or refuse to join the study. We ended up having 108 respondents.

Primary data were collected from these 108 respondents using structured interviews with open and closed interview guides. Secondary data came from documents, library studies, books, meeting minutes, joint decisions, and reports in the hydroponic groups and related agencies. Observations were also carried out to complete the data.

\subsection{Data Analysis}

a. Communication network analysis

Data on the communication network variable were analyzed descriptively through a complete network with an individual unit of analysis focusing on the actor's position in the network - the analysis employed the Communication Network Analysis (CNA) that resulted in relational data. Data were analyzed using UNICET Version 6.0 by applying the Adjacency Matrix (Full Matrix), in which actors were placed on the row and columns within a square matrix. Each actor was paired with other actors to see their relationship.

b. Descriptive Analysis

This analysis was carried out on the media gratification variable by categorizing the average score on Gratification Sought (GS) and Gratification Obtaines (GO) through the use of WA.

c. Analysis of the Relationship between Variables

The analysis explored the relationship between the centrality of actors in the hydroponic vegetable marketing network and the media gratification (on information, socialization, and social support). Spearman Rank correlation test using SPSS 21.0 for Windows program was applied to measure the non-parametric relationship between two variables.

\section{Results and Discussion}

\subsection{Actor identification and communication network analysis at the actor or individual level on the topics of hydroponic vegetable marketing}

\subsubsection{Identification of actors within the network}

Actor identification was based on the types and number of actors within the network, professional background, and residence. Actors in this study consisted of research respondents who lived in Situbondo and other actors (nonrespondents) who lived around Situbondo or outside Situbondo. The total number of actors in the network was 167 people.

One hundred sixty-four (164) respondents lived around Situbondo. One hundred eight (108) respondents were hydroponic farmers with the following codes: 1 to 108. There were 51 nonrespondent actors around Situbondo working as hydroponic farmers: 109, 111, 112, 113, 114, 
$115,116,117,119,120,121,123,124,125,126$, $128,129,130,131,132,133,134,135,136,137$, $138,139,140,141,142,143,144,145,146,147$, $148,149,150,151,152,153,154,155,156,157$, $158,159,163,164,165,167$. Some of them worked for the government agencies: one as the Head of Horticulture Infrastructure and Facilities (code 110) and one as an Agricultural Extension Officer (code 162). One respondent was a member of the Village Consultative Body (code 122). Two were sellers (code 160, 161). Respondents came from the 14 districts within Situbondo Regency (Situbondo, Panji, Kapongan, Panarukan, Mangaran, Kendit, Bungatan, Besuki, Banyuglugur, Sumbermalang, Jangkar, Arjasa, Asembagus, and Banyuputih District).

Three actors were from outside Situbondo as hydroponics farmers: two were hydroponic farmers (code 118 and 166) from Jember, and one was the head of the hydroponic farmer association and a hydroponic practitioner from Surabaya. The complete communication network structure in the sociogram was in a wheel structure.

Communication done by respondents through WA led to connections with other individuals within the network. All individuals in the network are called actors.

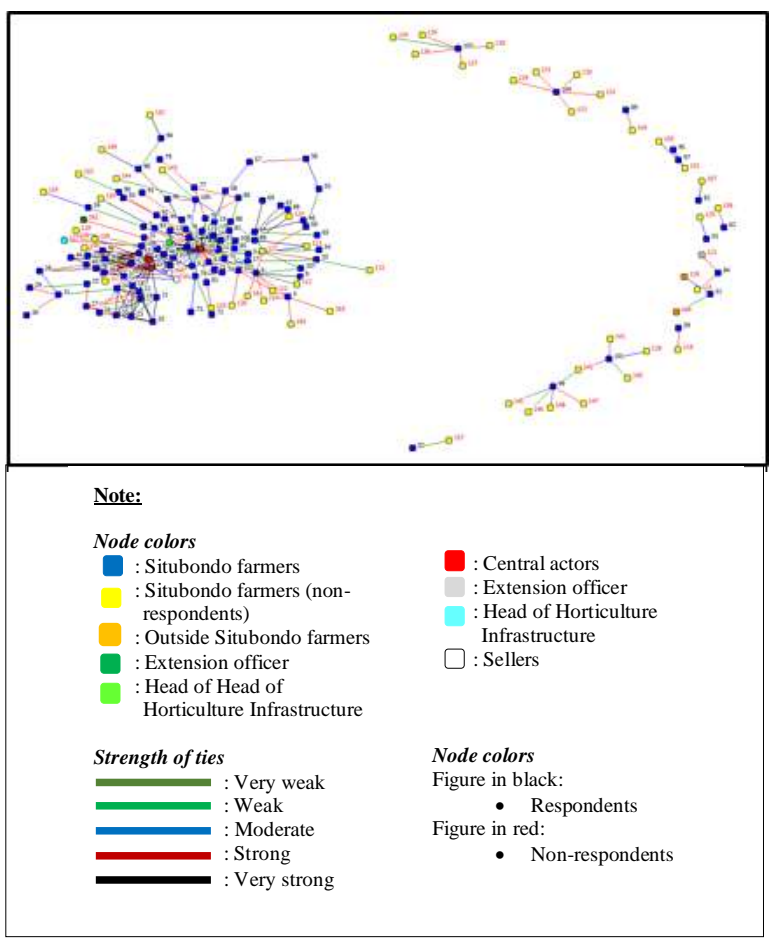

Figure 1. Sociogram of the communication network on the topic of hydroponic vegetable marketing
(Figure 1) It is almost certain that other actors outside the group will appear as a relationship effect from the data source actors, so it shows the wholeness of the network formed. Other actors can come from within the same area outside the farmer group (Mandar et al., 2017; Cahyono et al., 2019) or outside the farming activity system (Hertanto et al., 2016). In this internet-based study of networks via WA, other actors emerged from outside the area and the network group.

\subsubsection{Network analysis (actor centrality)}

Number of actor connections: (1) code 105: 46 ties $(15.86 \%)$ of a total of 290 ties; strength of ties: very weak $(\mathrm{SR})=12$ ties, weak $(\mathrm{R})=12$ ties, moderate $(\mathrm{S})=7$ ties, strong $(\mathrm{T})=$ 2 ties, very strong $(\mathrm{ST})=13$ ties. (2) Code $47: 27$ ties $(9.31 \%)$; strength of ties: $\mathrm{SR}=3$ ties, $\mathrm{R}=5$ ties, $\mathrm{S}=3$ ties, $\mathrm{T}=2$ ties, $\mathrm{ST}=14$ ties. (3) Code 41: 26 ties $(8.97 \%)$; strength of ties: $\mathrm{SR}=6$ ties, $\mathrm{R}=2$ ties, $\mathrm{S}=4$ ties, $\mathrm{T}=0$ ties, $\mathrm{ST}=14$ ties.

(Table 1) Findings suggested that their characteristics had caused the data source actors as a reference for other actors. The three data source actors were 39 years old (code 41), 30 years old (code 47), and 34 years old (code 105), so they were mature Millenials with sufficient experience and broad social relationships. They were young and energetic at their age. People in their productive age tend to make changes and act as an intermediary in the information flow (Hertanto et al., 2016). The older the age of the farmers, the more difficult it will be for them to establish a relationship with other actors due to their limited skills (Bulkis, 2015).

These three central actors had many connections with other actors in the virtual network through WA. They were also close to other actors, and they helped people in the network form such a bond (cutpoints). They were able to control information sharing (gatekeepers) and shared the information with other farmers or actors. They stated their opinions wisely (opinion leader) to other farmers, and they helped to make decisions. The three cebtral actors hold formal and non-formal positions in Situbondo, such as cadre-based economic movement (Pergerakan Ekonomi Berbasis Kader - PEBK) and Himpunan Pengusaha Santri Indonesia (HIPSI) of Nahdhotul Ulama (NU). Actors with code 41 and 47 were dedicated members of the "Jaya Abadi" Forest Farmer Group that empowered and assisted community groups like "Bangkit Jaya Mandiri (BJM)", "Republik Taman Reaggae", 
and others through non-formal training and dissemination. The actor code 105 was actively involved as a coordinator of a waste bank "Wijaya Mandiri", and supervised the youth organization for environment conservation, Ikatan Pemuda Dawuhan Peduli Lingkungan (IPADULI). The actor code 105 was also a resource person for hydroponic because he held a certificate of competence in hydroponic plant cultivation and had a hydroponic installation display in front of his house for activities on hydroponic technology innovation for the wider community. The maturity and experience of the young farmers helped them to build many good relationships and togetherness in the organizations they joined (Sulistiawati \& $\mathrm{P}$ Lubis, 2015).

The central actor code 41 graduated from a university (with a Diploma III and Sarjana S1 degree), code 47 graduated Senior High School, and code 105 graduated Junior High School. Interestingly, the central actor code 105 only graduated Junior High School, yet he had many experiences and sound knowledge on hydroponic. There are situations where formal education has nothing to do with the centrality degree or the popularity an individual gains in a network (Sulistiawati \& P Lubis, 2015). Information and ideas that help to solve problems are the main topic and factors within a communication network.
These three central actors were also involved in hydroponic for three years (actors code 41 and 47) and five years (actor code 105). Other farmers in the network were mainly beginners with less than a year of experience hydroponic. Their experience went hand in hand with the number of hydroponic planting holes they had to indicate the business capacity they run. Actor code 41 had 2,110 holes, actor code 47 had 6,000 holes, and actor code 105 had 3,300 holes. The number of holes was considered large compared to the average holes hydroponic farmers had in general, around \pm 200 holes per person. Experience represents the level of knowledge (information) one has, and it determines the utilization of agribusiness opportunities (Sains et al., 2009). The description above illustrates that three actors were eligible to be central actors in the network.

Experience farmers have will lead them to a very central role in disseminating agricultural information (Hertanto et al., 2016). Findings confirmed that many hydroponic farmers communicated with the central actors related to the price, availability, demand, and supply of hydroponic lettuce - they also shared problems and other information. The central actors continuously shared information and experience using WA in their smartphones (Singh Nain et al., 2019).

Table 1. Actor centrality on the topic of hydroponic vegetable marketing

\begin{tabular}{|c|c|c|c|c|}
\hline \multicolumn{4}{|c|}{ Actor centrality (node) } & \multirow{3}{*}{ Note } \\
\hline \multicolumn{4}{|c|}{ Centrality score } & \\
\hline Degree & Closeness & Betweenness & Eigenvector & \\
\hline 105 & 105 & 105 & 47 & \\
\hline 118 & 676 & 5239 & 0.424 & 1) \\
\hline 47 & 47 & 47 & 41 & \\
\hline 94 & 720 & 1372 & 0.376 & 2) \\
\hline 41 & 41 & 41 & 105 & \\
\hline 83 & 722 & 1080 & 0.282 & 3) \\
\hline
\end{tabular}

Note:

1) The first highest score of actor centrality

2) The second highest score of actor centrality

3) The third highest score of actor centrality

The central actors always did their best to ensure that the hydroponic lettuce market was in its best condition through intense communication with all farmers in the network. The farmers produced hydroponic lettuce from an imported variety known as Sementel by Bejo Seed and Batavia Lettuce by Rijk Zwaan (RZ). They chose those varieties because of their crunchy texture, a little bit of sweet flavor, and freshness - the two varieties are popular to be used in salads, sandwiches, and other beverages. Many people love them. Most hydroponic vegetables have no synthetic pesticide in them because they are cultivated without such substances. Customers of 
this hydroponic lettuce are the people living in elite housing and other social classes as well. Owners of catering, restaurants, and food stalls like kebabs from Situbondo and other places also become regular customers. The mutually agreed price at the farmer level is IDR 21.000 per kilogram. Customers and markets need around 50 kilograms of lettuce per day. The farmers sometimes send the lettuce via online courier services like Gojek, with the customers paying the delivery fee. Sometimes, the buyers come to the farmers, or the farmers send it themselves.

\subsection{WA Media Gratification}

The average score of farmer's expectation and satisfaction on information, socialization, and social support accommodated by WA was (GS) 4.31, 4.36, 4.25 dan (GO) 4.36, 4.44, 4.27. All these figures belonged to the "very high" category.

The following statement was cited from one of the actors (code 105) on the effort to ensure the availability of hydroponic lettuce using WA:

"... the market is available - it is wide open. We farmers even need more supply for the hydroponic lettuce... Situbondo needs 50 kilograms of lettuce per day... There is a high demand, very high indeed."

\subsubsection{Use of WA}

WA as a communication tool provides gratification for farmers related to their expectations through Gratification Sought (GS) that includes information, socialization, and social support they need. People choose media they consider able to fulfill their motives that fulfill their needs (Kriyantono, 2006). Information is defined as notification in messages related to marketing topics consisting of symbols or meanings that can be interpreted. Socialization is a communication process for millennial farmers to get to know, establish good interactions, and work together in networks. Social support is an effort by millennial farmers to give and receive empathy and sympathy, exchange opinions, and provide solutions to problems related to marketing topics.

Millenial hydroponic farmers in Situbondo had been using WA for more than six years on average. They chose WA at first compared to other communication media. Farmers can use WA to share information and experience to extend their knowledge (Singh Nain et al., 2019; Ardelia et al., 2020) or open access to market their products (Lestari et al., 2019; Relationship et al., 2021).

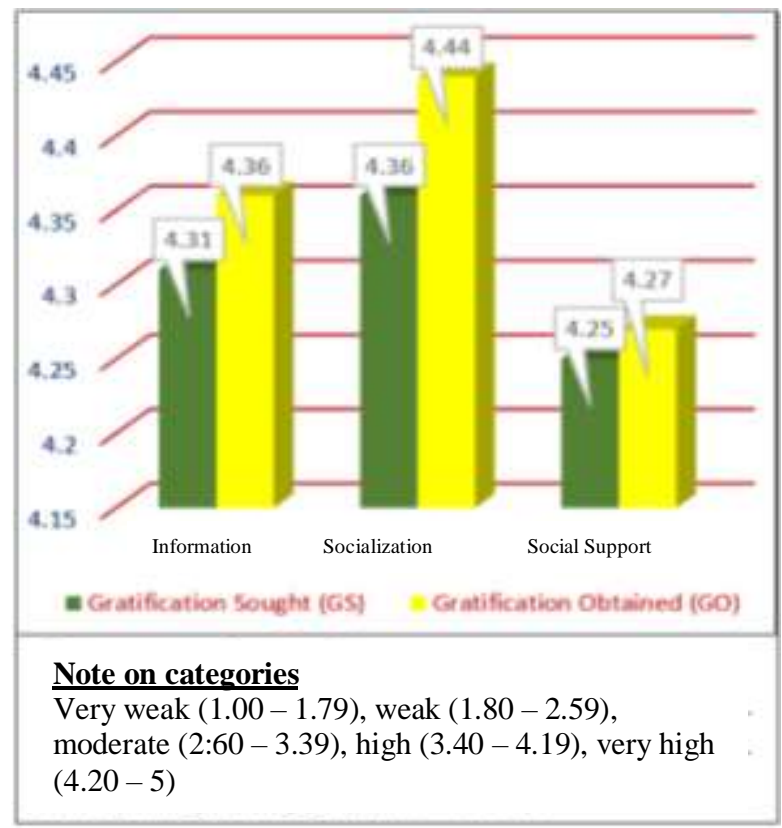

Figure 2. Average score chart: WA media Gratification Sought (GS) and Gratification Obtained (GO)

(Figure 2) Information: the farmers used WA to know information about the market for their products because it could lead to their income. The most important information is the current price of hydroponic lettuce, the market or consumers needing the product, the amount of lettuce needed, or ideas on hydroponic implemented by other farmers. The topic communicated intensively was the available stock in the market because the demand was quite high at around 50 kilograms per day. The actor code 105 often contacted other farmers via WA to manage hydroponic lettuce availability periodically and continuously based on market demand.

WA is one of the communication media that can provide information more effectively (Trisnani, 2017) and is an important medium in the marketing of agricultural products (Balkrishna \& Deshmukh, 2017; Global Journal of Management And Business Research, n.d.). Socialization: farmers believed that WA could fulfill their needs of experienced colleagues that understood hydroponic product marketing, so they could build a good network and cooperate with other farmers well. Social support: farmers needed to find solutions to their problems, get feedback from colleagues in the network under mutual appreciation, and discuss their business matters. WA helps individuals show their 
sympathy to others (Amna, 2018) and solve problems (Balkrishna \& Deshmukh, 2017; Global Journal of Management And Business Research, n.d.).

\subsubsection{Gratification obtained from the use of WA}

WA gave the farmers Gratification Obtained (GO) as they expected in communicating with other farmers through the network. The farmers found what they needed in Gratification Sought (GS). It is in line with Palmgreen et al. (1980) stating that the media can fulfill people's motives.

(Figure 2) Information: WA was able to meet the needs of the farmers to get information on marketing hydroponic vegetables. WA successfully played its role quickly with an easy way to present the farmers with the data, knowledge, and answers they needed. WA as an information medium plays a significant role in disseminating information and knowledge from one individual to others (Thakur et al., 2017; Sartika, 2018). Socialization: the hydroponic farmers were relatively young and did not have many connections with other people. WA helped them to find people to become their colleaguepeople that could work and cooperate with them in the marketing of hydroponic lettuce. The online social network has opened up rooms and opportunities for farmers to build relationships with other farmers (Kamani K C et al., 2016). Social support: WA opened up chances for gratification in social support for farmers to talk about their problems to other farmers in marketing the hydroponic product. The farmers found people who understood their problems and showed sympathy to them. They also could discuss the problems they faced to find solutions. Not limited to agriculture, WA media gratification also extends to other fields based on the user's need (Angelica et al., 2018; Adlani \& Hanifah, 2020). WA audiovisual features have helped to solve problems in agriculture (Naruka et al., 2017). Functional features offered by WA included chat, WhatsApp Call, WhatsApp Video Call, call, and video can accommodate farmers' needs. WA allows its users to share photos, videos, voice notes, and others to ease information sharing (Larasati in Rahartri, 2019). It can be done personally (one individual with another) or one individual with a group of other individuals (Suparmo, 2017). The farmers were satisfied with WA, as seen from the high score of GO compared to GS.

\subsection{The relationship of Millenial farmers' interpersonal network with the use and satisfaction on WA}

This study aimed to empirically prove the relationship between the interpersonal network of millennial hydroponic farmers (respondents) based on centrality measurement indicators (degree, closeness, betweenness, eigenvectors) with the gratification of WA as an online messaging application that focused on Gratification Sought (GS) and Gratification Obtained (GO) based on gratification dimensions (information, socialization, and social support). Statistical tests showed correlation and significance values for each correlated variable (Table 2).

Table 2. The relationship of millennial farmer's interpersonal networks on the use of and satisfaction on WA

\begin{tabular}{lcccccc}
\hline \multirow{2}{*}{ Research variables } & \multicolumn{9}{c}{ Gratification sought (GS) } \\
\cline { 2 - 7 } & \multicolumn{2}{c}{ Information } & \multicolumn{2}{c}{ Socialization } & \multicolumn{2}{c}{ Social support } \\
\cline { 2 - 7 } & rs & $\alpha$ & rs & $\alpha$ & rs & $\alpha$ \\
\hline Degree & 0.125 & 0.196 & $0.190^{*}$ & 0.049 & 0.161 & 0.095 \\
Closeness & -0.150 & 0.120 & $-0.251^{* *}$ & 0.009 & $-0.288^{* *}$ & 0.003 \\
Betweenness & 0.148 & 0.127 & $0.220^{*}$ & 0.022 & 0.162 & 0.095 \\
Eigenvector & 0.129 & 0.185 & $0.206^{*}$ & 0.033 & $0.191^{*}$ & 0.048 \\
\hline \multirow{2}{*}{ Research variables } & \multicolumn{7}{c}{ Gratification obtained (GO) } \\
\cline { 2 - 7 } & \multicolumn{2}{c}{ Information } & \multicolumn{2}{c}{ Socialization } & Social support \\
\cline { 2 - 7 } Degree & \multicolumn{2}{c}{ rs } & $\alpha$ & $\alpha$ & rs & $\alpha$ \\
Closeness & 0.187 & 0.053 & $0.310^{* *}$ & 0.001 & $0.275^{* *}$ & 0.004 \\
Betweenness & -0.144 & 0.137 & $-0.246^{*}$ & 0.010 & -0.133 & 0.171 \\
Eigenvector & 0.171 & 0.077 & $0.198^{*}$ & 0.040 & $0.215^{*}$ & 0.025 \\
& 0.118 & 0.225 & $0.247^{* *}$ & 0.010 & 0.129 & 0.183 \\
\hline
\end{tabular}


These data confirmed that the interpersonal communication network of millennial hydroponic farmers was significantly or very significantly related to WA media gratification on the socialization dimension of both GS and GO. A significant relationship was shown by degree centrality (GS), betweenness centrality (GS), eigenvector centrality (GS), closeness centrality (GO), and betweenness centrality (GO). A very significant relationship was found on closeness centrality (GS), degree centrality (GO), and eigenvector centrality (GO). It means that the higher the degree centrality of a hydroponic farmer (popularity), betweenness centrality (liaison for other farmers), and eigenvector centrality (relationships with important individuals in the network), then the higher their WA utilization level to achieve socialization desires, namely finding and getting to know hydroponic farmers or individuals or other colleagues and establishing good relationships for collaborating. Meanwhile, the higher the betweenness centrality of a hydroponic farmer, the higher the achievement level on their desires facilitated by WA functional quality. The higher the eigenvector centrality of a hydroponic farmer, the higher the achievement level on their socialization desires facilitated by WA functional quality. High WA utilization by central actors aimed to achieve success in marketing lettuce (Relationship et al., 2021).

Meanwhile, closeness centrality and the socialization dimension of GS show a negative and significant relationship. It means the farmers having more distant relationships with other individuals in the network (low closeness centrality) tended to utilize WA more to achieve their desire to find and get to know other hydroponic farmers or individuals or colleagues to establish good relationships with them. It happens because those individuals expect that a good relationship will help them to market their lettuce better. Working alone (solitary) does not make marketing efforts work well. Often the central actor becomes a role model and reference for novice hydroponic farmers wanting to find information (Puttileihalat, 2019) through socialization. The same condition occurred in the relationship between closeness centrality and the socialization dimension (GO), showing a negative and significant relationship. The farmers having a longer distance relationship with other individuals in the network (low closeness centrality level) might expect to socialize better with the help of WA functional quality.

The negative and significant relationship also happened to closeness centrality and social support (GS). It means that the lower the closeness centrality of farmers, the more they utilized WA to achieve their desire of getting social support. Findings confirmed that the farmers having more distant relationships with other individuals in the network (low closeness centrality) were more willing to use WA to discuss problems related to lettuce marketing with other farmers in the network to get solutions. It was rather different from the significant relationship between eigenvector centrality and the social support dimension in GS. Findings showed that the higher the eigenvector centrality (farmers had better relationships with other individuals in the network), the higher they utilized WA for social support. These farmers wanted to show their empathy and discuss problems related to the marketing of hydroponic lettuce with other farmers in the network. They wanted to find the core of the problems to be communicated with important individuals as their colleagues to find solutions.

A significant relationship was found on degree centrality with the dimension of social support (GO). The higher the degree centrality of farmers or the more popular they were, the more successful they were in giving social support through WA functional quality. The relationship between betweenness centrality and the social support dimension (GO) was significant. It means the higher the betweenness centrality the farmers had (the better their ability in connecting people in the network), the more successful they were in giving social support through WA functional quality. These farmers wanted to show their empathy and discuss problems related to the marketing of hydroponic lettuce with other farmers in the network.

Efforts to use internet-based WA by farmers as central and non-central actors in the network in this study strengthened the findings to other research with similar topics such as by Kamani K C et al. (2016) and Puttileihalat (2019) regarding the importance of a central actor in the dissemination of knowledge or information on agribusiness and agricultural products in Indonesia. Relationship et al. (2021) explored the relationship between the frequency of WA use and the success of marketing agricultural 
products. Balkrishna \& Deshmukh (2017) in Global Journal of Management And Business Research, n.d.) discussed social media (internetbased) that was useful in agricultural marketing.

\section{Conclusions}

a. Communication on the topic of marketing of hydroponic lettuce by farmers in Situbondo via WA to form a whole network helped emerge other actors from various professions and backgrounds in the network, both from Situbondo and from outside Situbondo. The structure of the communication network as a whole forms a wheel structure. The communication relationship formed in the network was still not evenly distributed. Three actors (code 41, 47, and 105) dominated it, which occupied four kinds of centrality (degree, closeness, betweenness, and eigenvector).

b. The level of WA usage and satisfaction obtained by millennial hydroponic farmers was very high for all three dimensions (information, socialization, and social support).

c. The hydroponic farmer interpersonal network and WA media gratification had a significant and very significant relationship with the four types of centrality in the socialization dimension (GS and GO), with closeness and eigenvector centrality in the social support dimension (GS), and degree and betweenness centrality in the social support dimension (GO). The communication process will be effective by utilizing central actors, especially building solid relationships in the network and when problems occur related to hydroponic vegetable marketing.

\section{Reference}

A Study on Role of Social Media in Agriculture Marketing and its Scope| Global Journal of Management And Business Research. (n.d.). Retrieved July 6, 2021, from https://journalofbusiness.org/index.php/GJ MBR/article/view/2245

Adlani, N., \& Hanifah, M. (2020). Media Alternatif Whatsapp (WA) Mengatasi Permasalahan Pembelajaran pada Situasi Pendemi Covid 19 di Kelas PGMI Semester IV. At-Thullab: Jurnal Pendidikan Guru Madrasah Ibtidaiyah,
4(2),

93.

https://doi.org/10.30736/atl.v4i2.215

Amna, A. (2018). Whatsapp (Wa) Dan Konsep Jarak Sosial Baru Di Masyarakat. Expose: Jurnal Ilmu Komunikasi, 1(2), 134. https://doi.org/10.33021/exp.v1i2.445

Analisis Jaringan Komunikasi - Eriyanto Google Buku. (n.d.). Retrieved June 27, 2021, from https://books.google.nl/books? $\mathrm{id}=\mathrm{iK} 5 \mathrm{oDw}$ AAQBAJ\&printsec $=$ frontcover\&dq=Anali sis+Jaringan+Komunikasi\& $\mathrm{hl}=\mathrm{id} \& \mathrm{sa}=\mathrm{X} \& \mathrm{r}$ edir_esc $=\mathrm{y} \# \mathrm{v}=$ onepage $\& \mathrm{q}=$ Analisis Jaringan Komunikasi\&f=false

Angelica, N., Priyowidodo, G., \& ... (2018). Interaksi Kelompok Micin melalui Whatsapp dalam Menghadapi Permasalahan Anak. Jurnal E-Komunikasi. http://publication.petra.ac.id/index.php/ilm u-komunikasi/article/view/8337

Ardelia, R., Anwarudin, O., \& Nazaruddin. (2020). Akses Teknologi Informasi melalui Media Elektronik pada Petani KRPL. Jurnal Triton, 11(1), 24-36. https://doi.org/10.47687/jt.v11i1.101

Bae, M. (2018). Understanding the effect of the discrepancy between sought and obtained gratification on social networking site users' satisfaction and continuance intention. Computers in Human Behavior, 79(November), 137-153. https://doi.org/10.1016/j.chb.2017.10.026

Beaman, L., \& Dillon, A. (2018). Diffusion of agricultural information within social networks: Evidence on gender inequalities from Mali. Journal of Development Economics, 133, 147-161. https://doi.org/10.1016/j.jdeveco.2018.01.0 09

Bonacich_1987.Pdf. (n.d.).

Bondad-Brown, B. A., Rice, R. E., \& Pearce, K. E. (2012). Influences on TV Viewing and Online User-shared Video Use: Demographics, Generations, Contextual Age, Media Use, Motivations, and Audience Activity. Journal of Broadcasting and Electronic Media, 56(4), 471-493. https://doi.org/10.1080/08838151.2012.73 2139 
Bulkis. (2015). Analisis Jaringan Komunikasi Petani Tanaman Sayuran (Kasus Petani Sayuran Di Desa Egon , Kecamatan Waigette , Kabupaten. Jurnal Matematika, Saint, Dan Teknologi, 16(2), 28-42.

Cahyono, E. D., Ariza, M. F. U., \& Sukesi, K. (2019). Communication Network Analysis in Drip Irrigation Technology Application for Chrysanthemum Flower Cultivation Agrilan. Jurnal Agribisnis Kepulauan, 7(2), 181-196.

Communication Networks: Toward a New Paradigm for Research - Everett $M$. Rogers, D. Lawrence Kincaid - Google Buku. (n.d.). Retrieved June 27, 2021, from https://books.google.nl/books?id=r3tiAAA AMAAJ\&q=Communication+Networks $+\mathrm{T}$ owards+a+New+Paradigm+for+Research $\& \mathrm{dq}=$ Communication+Networks+Towards $+\mathrm{a}+\mathrm{New}+$ Paradigm + for + Research\&hl=id $\& s a=X \&$ redir_esc $=y$

Daum, T. (2018). ICT applications in agriculture. In Encyclopedia of Food Security and Sustainability (pp. 255-260). Elsevier. https://doi.org/10.1016/B978-0-08100596-5.22591-2

Dlamini, M. M., \& Worth, S. (2019). The Potential and Challenges of Using ICT as a Vehicle for Rural Communication as Characterised by Smallholder Farmers. Asian Journal of Agricultural Extension, Economics \& Sociology, 34(3), 1-10. https://doi.org/10.9734/ajaees/2019/v34i33 0202

Freeman, D. C. A. \& C. K. (2016). Journal of Development and Communication Studies, 2016

4(2), 443-453.

Gallo, E. (2020). Communication networks in markets. European Economic Review, 129, 103545.

https://doi.org/10.1016/j.euroecorev.2020. 103545

Han, S., Min, J., \& Lee, H. (2015). Antecedents of social presence and gratification of social connection needs in SNS: A study of Twitter users and their mobile and nonmobile usage. International Journal of Information Management, 35(4), 459-471. https://doi.org/10.1016/j.ijinfomgt.2015.04 .004

Hertanto, D., Sugiyanto, S., \& Safitri, R. (2016). Analisis Struktur Jaringan Komunikasi dan Peran Aktor Dalam Penerapan Teknologi Budidaya Kentang (Petani Kentang Desa Ngantru Kecamatan Ngantang Kabupaten Malang). Habitat, 27(2), 55-65. https://doi.org/10.21776/ub.habitat.2016.0 27.2.7

Kamani K C, Ghodasara Y R, Soni N V, \& Parsaniya, A. (2016). Empowering Indian Agriculture With Whatsapp - a Positive Step Towards Digital India. International Journal of Agriculture Sciences, 8(13), 975-3710.

Király, O., Potenza, M. N., Stein, D. J., King, D. L., Hodgins, D. C., Saunders, J. B., Griffiths, M. D., Gjoneska, B., Billieux, J., Brand, M., Abbott, M. W., Chamberlain, S. R., Corazza, O., Burkauskas, J., Sales, C. M. D., Montag, C., Lochner, C., Grünblatt, E., Wegmann, E., ... Demetrovics, Z. (2020). Preventing problematic internet use during the COVID-19 pandemic: Consensus guidance. Comprehensive Psychiatry, 100, $1-4$.

https://doi.org/10.1016/j.comppsych.2020. 152180

Kizgin, H., Jamal, A., Rana, N., Dwivedi, Y., \& Weerakkody, V. (2019). The impact of social networking sites on socialization and political engagement: Role of acculturation. Technological Forecasting and Social Change, 145(September), 503512.

https://doi.org/10.1016/j.techfore.2018.09. 010

Lestari, N., Amanah, S., Muljono, P., \& Susanto, D. (2019). Pengaruh Profil Petani Pengelola Agrowisata terhadap Kapasitas Pemanfaatan Teknologi Komunikasi Digital di Kabupaten Bojonegoro dan Malang, Provinsi Jawa Timur. AGRARIS: Journal of Agribusiness and Rural Development Research, 5(1). https://doi.org/10.18196/agr.5176

Majid, M., Khan, J. N., Ahmad Shah, Q. M., Masoodi, K. Z., Afroza, B., \& Parvaze, S. (2021). Evaluation of hydroponic systems for the cultivation of Lettuce (Lactuca 
sativa L., var. Longifolia) and comparison with protected soil-based cultivation. Agricultural Water Management, 245, 106572.

https://doi.org/10.1016/j.agwat.2020.10657 2

Mandar, P., Sulawesi, W., Raharjo, A., Muljono, P., \& Matindas, K. (2017). Jaringan Komunikasi Pemasaran Kakao Di Kecamatan Anreapi, Kabupaten Polewali Mandar, Provinsi Sulawesi Barat. Jurnal Komunikasi Pembangunan, 15(1), 1-14. https://doi.org/10.29244/jurnalkmp.15.1.

Min, S., Liu, M., \& Huang, J. (2020). Does the application of ICTs facilitate rural economic transformation in China? Empirical evidence from the use of smartphones among farmers. Journal of Asian Economics, 70, 101219. https://doi.org/10.1016/j.asieco.2020.1012 19

Naruka, P., Verma, S., Sarangdevot, S., Pachauri, C., Kerketta, S., \& Singh, J. (2017). A Study on Role of WhatsApp in Agriculture Value Chains. Asian Journal of Agricultural Extension, Economics \& Sociology, 20(1), 1-11. https://doi.org/10.9734/ajaees/2017/36498

Palmgreen, P., Wenner, L. A., \& Rayburn, J. D. (1980). Relations between gratifications sought and obtained: A Study of Television News. Communication Research, 7(2), 161-192. https://doi.org/10.1177/009365028000700 202

Profit, M., Study, A. C., \& Farmers, A. (2021). Does Internet and Information Technology Help Farmers to.

Puttileihalat, P. M. (2019). Popularity Level and Role of Actors in the Degree Centrality Network of Eucalyptus Oil Processor Farmers in Waisala Village, West Seram Regency, Maluku Province. 104-109.

Rahartri. (2019). "Whatsapp" Media Komunikasi Efektif Masa Kini (Studi Kasus Pada Layanan Jasa Informasi Ilmiah di Kawasan Puspiptek). Visi Pustaka, 21(2), 147-156.

Real, F., Batou, A., Ritto, T., \& Desceliers, C. (2019). Stochastic modeling for a hysteretic bit-rock interaction of a drill string under torsional vibrations. Journal of Vibration and Control, X, 107754631982824.

https://doi.org/10.1177/ToBeAssigned

Relationship, T., Whatsapp, B., Frequency, U., District, S., Nugroho, I., Sumekar, W., Prayoga, K., \& Diponegoro, U. (2021). AGROLAND: JURNAL ILMU-ILMU PERTANIAN The Relationship Between WhatsApp Usage Frequency and Success of Coffee. 28(1), 17-31.

Ruhnau, B. (2000). Eigenvector-centrality - a node-centrality. Social Networks, 22(4), 357-365. https://doi.org/10.1016/S03788733(00)00031-9

Sains, D., Dan, K., Masyarakat, P., \& Manusia, F. E. (2009). Departemen sains komunikasi dan pengembangan masyarakat fakultas ekologi manusia institut pertanian bogor 2009. 5(1).

Sartika. (2018). Kegunaan whatsapp sebagai media informasi dan media pembelajaran pada mahasiswa ilmu komunikasi STISIP persada bunda. Medium, 6(2), 15-26.

Shensa, A., Sidani, J. E., Escobar-Viera, C. G., Switzer, G. E., Primack, B. A., \& Choukas-Bradley, S. (2020). Emotional support from social media and face-to-face relationships: Associations with depression risk among young adults. Journal of Affective Disorders, 260, 38-44. https://doi.org/10.1016/j.jad.2019.08.092

Shensa, A., Sidani, J. E., Lin, L. Yi, Bowman, N. D., \& Primack, B. A. (2016). Social Media Use and Perceived Emotional Support Among US Young Adults. Journal of Community Health, 41(3), 541-549. https://doi.org/10.1007/s10900-015-0128-8

Singh Nain, M., Singh, R., \& Mishra, J. R. (2019). Social networking of innovative farmers through WhatsApp messenger for learning exchange: A study of content sharing. Indian Journal of Agricultural Sciences, 89(3), 556-558.

Social Network Analysis: A Handbook - John Scott - Google Buku. (n.d.). Retrieved July 6, 2021, from https://books.google.nl/books?id=okSev70 ua3gC\&pg=PR3\&dq=Scott.+Social+Netw ork+Analysis: $+\mathrm{A}+$ Handbook. \&hl=id\&sa= X\&ved=2ahUKEwjUz7ulks3xAhUO76Q KHau1C7oQ6AF6BAgKEAI\#v=onepage 
$\& q=$ Scott. Social Network Analysis\%3A A Handbook. \&f $=$ false

Sulistiawati, A., \& P Lubis, D. (2015). Analisis Jaringan Sosial Dalam Gabungan Kelompok Tani (Gapoktan) Tani Berkah. Sodality: Jurnal Sosiologi Pedesaan, 2(2), 76-82.

https://doi.org/10.22500/sodality.v2i2.9415

Suparmo, L. (2017). Uses and Gratifications Theory dalam Media Sosial WA (WhatsApp). Communicology: Jurnal Ilmu Komunikasi, 5(2), 27-37. https://doi.org/10.21009/communicology.0 62.02

Teknik Praktis Riset komunikasi - Rachmat Kriyantono, S.Sos., M.Si - Google Buku. (n.d.). Retrieved June 27, 2021, from https://books.google.nl/books?id=gI9ADw AAQBAJ\&printsec $=$ frontcover\&dq $=$ Tekni s+praktis+riset+komunikasi\&hl $=\mathrm{id} \& \mathrm{sa}=\mathrm{X}$ \&redir_esc $=\mathrm{y} \# \mathrm{v}=$ onepage $\& \mathrm{q}=$ Teknis praktis riset komunikasi\&f $=$ false

Thakur, D., Chander, M., \& Sinha, S. (2017). Whatsapp for Farmers: Enhancing the Scope and. 6(4), 2190-2201.

Trisnani, -. (2017). Pemanfaatan Whatsapp Sebagai Media Komunikasi Dan Kepuasan Dalam Penyampaian Pesan Dikalangan Tokoh Masyarakat. Jurnal Komunika: Jurnal Komunikasi, Media Dan Informatika, 6(3). https://doi.org/10.31504/komunika.v6i3.12 27

Trujillo Loli, Y., D’Carlo Trejo Huamán, M., \& Campos Medina, S. (2021). Telementoring of in-home real-time laparoscopy using WhatsApp messenger: An innovative teaching tool during the COVID-19 pandemic. A cohort study. Annals of Medicine and Surgery, 62(December 2020), 481-484. https://doi.org/10.1016/j.amsu.2021.01.085

Wehmuth, K., \& Ziviani, A. (2013). DACCER: Distributed Assessment of the Closeness CEntrality Ranking in complex networks. Computer Networks, 57(13), 2536-2548. https://doi.org/10.1016/j.comnet.2013.05.0 01

White, D., Meyers, C., Doerfert, D., \& Irlbeck, E. (2014). Exploring Agriculturalists' Use of Social Media for Agricultural Marketing.
Journal of Applied Communications, 98(4). $\quad$ https://doi.org/10.4148/10510834.1094

Zhang, J., \& Luo, Y. (2017). Degree Centrality, Betweenness Centrality, and Closeness Centrality in Social Network. 132(Msam), 300-303. https://doi.org/10.2991/msam17.2017.68

Available online at HABITAT website: http://www.habitat.ub.ac.id ISSN: 0853-5167 (p); 2338-2007 (e) 